\title{
A Facile Spectrophotometric Method for the Determination of Periodate Using Azure B
}

\author{
B. Narayana* and Tom Cherian \\ Department of Post Graduate Studies and Research in Chemistry, Mangalore University, \\ Mangalagangothri - 574 199, India
}

\begin{abstract}
Foi desenvolvido um método simples, rápido e sensível para a determinação de periodato em amostras de água de rio e em solução. O método é baseado na reação do periodato com iodeto em meio ácido, com liberação de iodo. O iodo liberado diminui a intensidade da cor violeta do azure B, medida em $644 \mathrm{~nm}$. O decaimento da absorbância é diretamente proporcional a concentração de periodato e obedece a lei de Beer na faixa de 0,2 -5,5 $\mu \mathrm{g} \mathrm{mL}^{-1}$. A absortividade molar, a sensibilidade de Sandell e os limites de detecção e de quantificação encontrados foram $1,09 \times 10^{5} \mathrm{~L} \mathrm{~mol}^{-1} \mathrm{~cm}^{-1}, 1,75 \times 10^{-3} \mu \mathrm{g} \mathrm{cm}^{-2}, 0,07 \mu \mathrm{g} \mathrm{mL}{ }^{-1}$ and $0,20 \mu \mathrm{g}$ $\mathrm{mL}^{-1}$, respectivamente. As condições ótimas de reação e os parâmetros analíticos foram avaliados. O efeito de íons interferentes é descrito. O método proposto foi aplicado com sucesso na determinação de periodato em amostras de águas de rio e em solução.
\end{abstract}

A simple, rapid and sensitive spectrophotometric method has been developed for the determination of periodate in solution and river water samples. The method is based on the reaction of periodate with iodide in an acid medium to liberate iodine. This liberated iodine bleaches the violet color of the azure B and is measured at $644 \mathrm{~nm}$. This decrease in absorbance is directly proportional to the periodate concentration and obeys Beer's law in the range of $0.2-5.5$ $\mu \mathrm{g} \mathrm{mL}^{-1}$. The molar absorptivity, Sandell's sensitivity, detection limit and quantitation limit of the method were found to be $1.09 \times 10^{5} \mathrm{~L} \mathrm{~mol}^{-1} \mathrm{~cm}^{-1}, 1.75 \times 10^{-3} \mu \mathrm{g} \mathrm{cm}^{-2}, 0.07 \mu \mathrm{g} \mathrm{mL}^{-1}$ and $0.20 \mu \mathrm{g}$ $\mathrm{mL}^{-1}$ respectively. The optimum reaction conditions and other analytical parameters were evaluated. The effect of interfering ions on the determination is described. The proposed method has been successfully applied to the determination of periodate in solutions and river water samples.

Keywords: periodate determination, spectrophotometry, azure B

\section{Introduction}

The determination of iodine compounds, particularly periodate, I(VII) is important in organic chemistry, biology and life sciences, but it is rather difficult to determine I(VII) at low concentrations. Periodate is used for the oxidation of different inorganic, organic compounds and catalytic applications at trace levels..$^{1-6}$ Therefore simple, rapid, sensitive and accurate method is required for the determination of trace amounts of periodate in different samples.

Many methods have been reported for the determination of periodate, such as thin layer chromatography, ${ }^{7}$ capillary zone electrophoresis, ${ }^{8}$ pulse polarography, ${ }^{9}$ fluorometry ${ }^{10}$

Chemeluminiscence. ${ }^{3}$ Some of the reported chromogenic reagents for the spectrophotometric determination of periodate are 5,5-dimethyl-1,3-cyclohexanedione bisthiosemicarbazone monohydrochloride,$^{11}$ amodiaquine dihydrochloride, ${ }^{12}$ ferroin, ${ }^{13}$ o- dianisidine, ${ }^{14} 4$ - bromo-N,N'-

* e-mail: nbadiadka@yahoo.co.uk bis ( 2- hydroxypropyl)-o- phenylenediamine, ${ }^{15} 2,2$ '- azinodi (3- ethylbenzothiazol-6-sulphonate) ${ }^{16}$ Of these reagents, few are reported to be carcinogenic while few others are less selective, less sensitive, time consuming and suffer from small calibration range. The need for a sensitive simple reliable method for the determination of periodate is therefore clearly recognized.

In this work a new spectrophotometric method is described for the determination of trace quantities of periodate based on the reaction with azure B. The proposed method is rapid, simple, precise and accurate and is suitable for the determination of periodate in solution and different river water samples.

\section{Experimental}

\section{Apparatus}

A Secomam Anthelie NUA 002 UV - Visible 
spectrophotometer with $1 \mathrm{~cm}$ quartz cell was used for the absorbance measurements and a WTW pH 330, pH meter was used.

\section{Reagents}

All chemicals used were of analytical reagent or chemically pure grade and double distilled water was used throughout the study. A standard stock solution $(1000 \mu \mathrm{g}$ $\mathrm{mL}^{-1}$ ) of periodate was prepared by dissolving $0.1205 \mathrm{~g}$ of potassium periodate in $100 \mathrm{~mL}$. Hydrochloric acid ( $2 \mathrm{~mol}$ $\left.\mathrm{L}^{-1}\right), 2 \%$ potassium iodide, acetate buffer of $\mathrm{pH} 4$ were used. A $0.05 \%$ solution of azure B was prepared by dissolving $0.05 \mathrm{~g}$ of azure $\mathrm{B}$ (molecular weight $=305.83$ ) in $25 \mathrm{~mL}$ methanol and made up to $100 \mathrm{~mL}$ with distilled water.

\section{Procedure}

Sample solution containing $0.2-5.5 \mu \mathrm{g} \mathrm{mL} \mathrm{m}^{-1}$ of periodate was transferred into a series of $10 \mathrm{~mL}$ calibrated flasks, potassium iodide $(2 \%(\mathrm{~m} / \mathrm{v}), 1 \mathrm{~mL})$ then hydrochloric acid ( $2 \mathrm{~mol} \mathrm{~L}^{-1}, 1 \mathrm{~mL}$ ) were added and the reaction mixture was gently shaken until the appearance of yellow color, indicating the liberation of iodine. Azure $\mathrm{B}(0.05 \%, 0.5 \mathrm{~mL})$ was then added and the reaction mixture mixture shaken for 2 minutes. The $\mathrm{pH}$ of the medium was adjusted by using acetate buffer of $\mathrm{pH} 4$, then the contents were diluted to $10 \mathrm{~mL}$ with distilled water and mixed well. The absorbance of the resulting solution was measured at $644 \mathrm{~nm}$ against reagent blank. The amount of the periodate present in the volume taken was computed from the calibration graph.

\section{Determination of periodate in river water samples}

An aliquot of the spiked samples containing not more than $5.5 \mu \mathrm{g} \mathrm{mL}^{-1}$ of the periodate was treated with $1 \mathrm{~mL}$ of $2 \%$ potassium iodide reagent followed by $1 \mathrm{~mL}$ of 2 mol L $\mathrm{L}^{-1}, \mathrm{HCl}$. The mixture was shaken well until the appearance of yellow color and then $0.5 \mathrm{~mL}$ of $0.05 \%$ azure B solution was added. The $\mathrm{pH}$ of the medium was adjusted by using acetate buffer of $\mathrm{pH} 4$, then the contents were diluted to $10 \mathrm{~mL}$ with distilled water and mixed well. The absorbance of the resulting solution was measured at $644 \mathrm{~nm}$ against reagent blank .

\section{Results and Discussion}

The absorption spectrum of the azure B ( violet colored species) is presented in Figure 1 and the reaction mechanism is represented in Scheme 1.

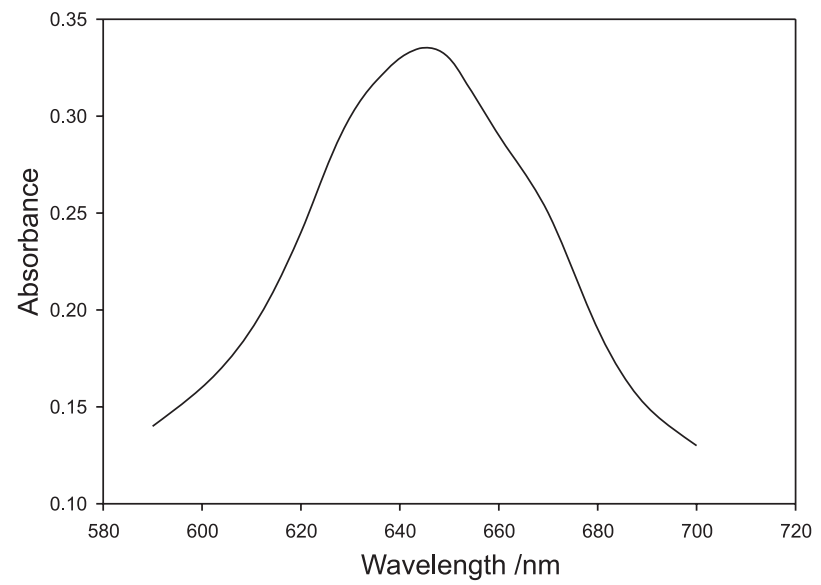

Figure 1. Absorption spectrum of colored species azure B; [azure B] $=0.05 \%$.

$$
\mathrm{IO}_{4}^{-}+8 \mathrm{I}^{+}+8 \mathrm{H}^{+} \longrightarrow 4 \mathrm{H}_{2} \mathrm{O}+3 \mathrm{I}_{3}^{-}
$$

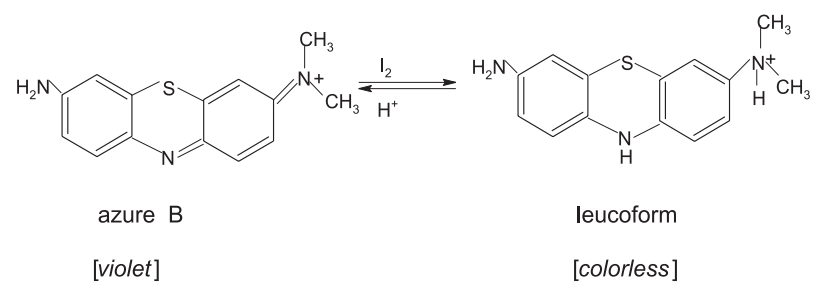

Scheme 1.

\section{Effect of iodide concentration and acidity}

The effect of iodide concentration and acidity on the decolorization was studied with $1 \mu \mathrm{g} \mathrm{mL}^{-1}$ periodate solution. The oxidation of iodide to iodine was effective in the $\mathrm{pH}$ range 1.0 to 1.5 , which could be maintained by adding $1 \mathrm{~mL}$ of $2 \mathrm{~mol} \mathrm{~L}^{-1} \mathrm{HCl}$ in a final volume of $10 \mathrm{~mL}$. The liberation iodine from $\mathrm{KI}$ in an acid medium was quantitative. The appearance of yellow color indicates the liberation of iodine. Although any excess of iodide in the solution will not interfere. It was found that $1-1.2 \mathrm{~mL}$ of $2 \% \mathrm{KI}$ and $1 \mathrm{~mL}$ of 2 $\mathrm{mol} \mathrm{L} \mathrm{L}^{-1} \mathrm{HCl}$ were sufficient for the liberation of iodine from iodide by periodate and $0.5 \mathrm{~mL}$ of $0.05 \%$ azure $\mathrm{B}$ was used for subsequent decolorization. Effect of concentration of potassium iodide in reaction system is presented in Figure 2.

\section{Effect of $p H$}

The variation of absorbance of known concentration of the periodate with $\mathrm{pH}$ of the medium was studied. A series of buffer solution differing by $\mathrm{pH} 1$ was prepared, and using each of these buffer, system was studied. The maximum absorbance value was found at $\mathrm{pH} 4$. Hence, the $\mathrm{pH}$ was maintained at four throughout the study by using acetate buffer of $\mathrm{pH} 4$. Effect of $\mathrm{pH}$ on color intensity is shown in Figure 3. 


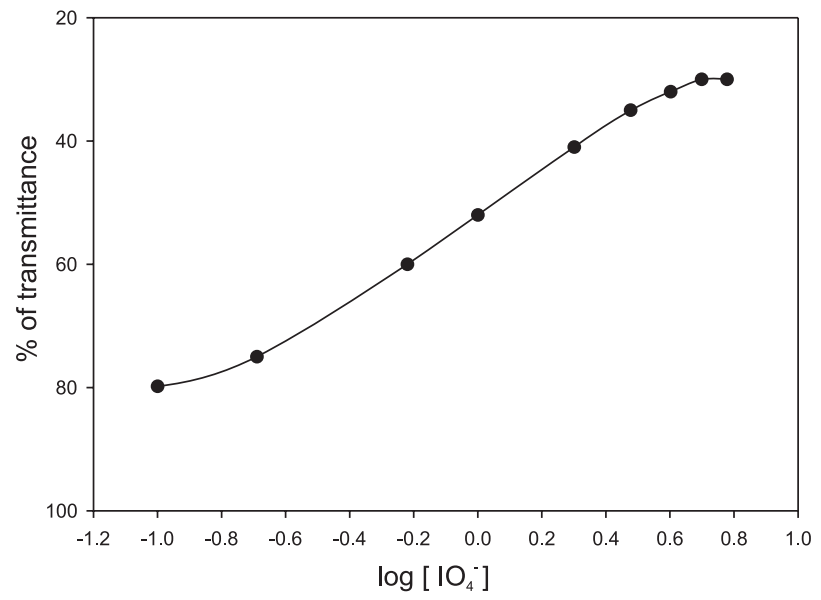

Figure 2. Ringbom's plot for the periodate- azure B system;reagents concentration: $[\mathrm{HCl}]=2 \mathrm{~mol} \mathrm{~L}^{-1},[\mathrm{KI}]=2 \%$, [azure $\left.\mathrm{B}\right]=0.05 \%$.

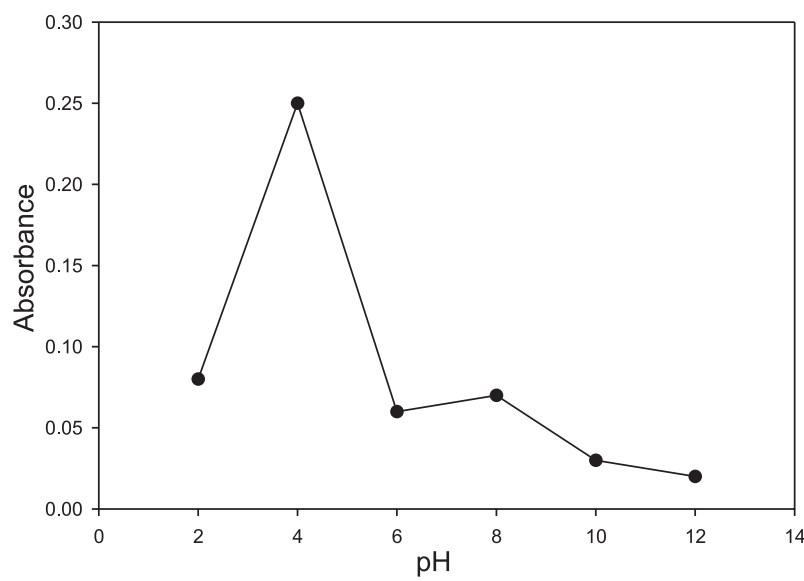

Figure 3. Effect of $\mathrm{pH}$ on color intensity; reagents concentration: $\left[\mathrm{IO}_{4}^{-}\right]=1 \mu \mathrm{g} \mathrm{mL}^{-1},[\mathrm{HCl}]=2 \mathrm{~mol} \mathrm{~L}^{-1},[\mathrm{KI}]=2 \%$, [azure B] $=0.05 \%$.

\section{Analytical data}

The adherence to Beer's law was studied by measuring the absorbance values of solutions varying periodate concentration. A straight line graph was obtained by plotting absorbance against concentration of periodate. Beer's law obeyed in the range of $0.2-5.5 \mu \mathrm{g} \mathrm{mL}^{-1}$ of periodate. The molar absorptivity and Sandell's sensitivity for colored system was found to be $1.09 \times 10^{5} \mathrm{~L} \mathrm{~mol}^{-1} \mathrm{~cm}^{-1}, 1.75 \times 10^{-3} \mu \mathrm{g} \mathrm{cm}^{-2}$ respectively. The detection limit $\left(D_{L}=3.3 \sigma / S\right)$ and quantitation limit $\left(\mathrm{Q}_{\mathrm{L}}=10 \sigma / \mathrm{S}\right)$ [where $\sigma$ is the standard deviation of the reagent blank $(n=5)$ and $S$ is the slope of the calibration curve] for the periodate determination were found to be $0.07 \mu \mathrm{g} \mathrm{mL}^{-1}$ and $0.20 \mu \mathrm{g} \mathrm{mL}^{-1}$ respectively. Ringbom's plot for the periodate determination is shown in Figure 2.

\section{Effect of interfering ions}

The effect of various ions at $\mu \mathrm{g} \mathrm{mL}-1$ levels on the determination of periodate was examined. The tolerance limits

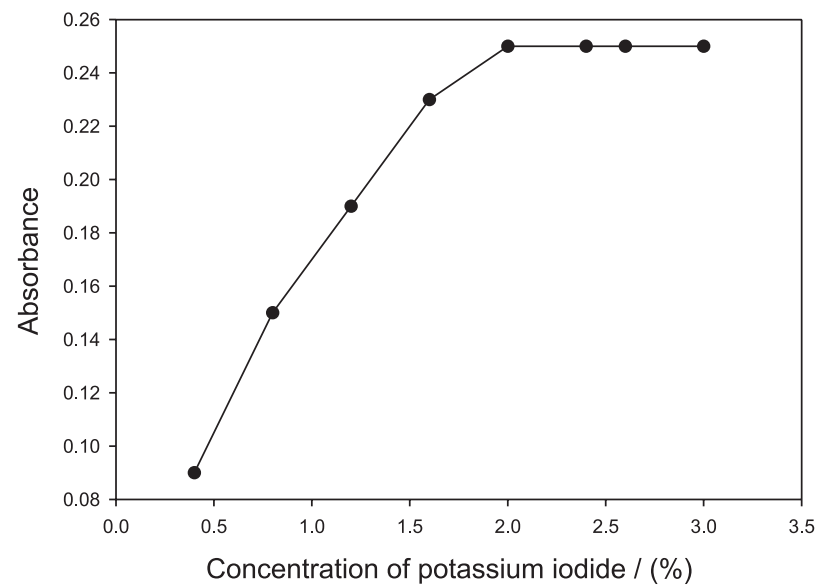

Figure 4. Effect of concentration of potassium iodide; reagents concentration: $\left[\mathrm{IO}_{4}^{-}\right]=2 \mu \mathrm{g} \mathrm{mL} \mathrm{L}^{-1},[\mathrm{HCl}]=2 \mathrm{~mol} \mathrm{~L}^{-1}$, [azure B] $=$ $0.05 \%$, Acetate buffer $\mathrm{pH} 4$.

Table 1. Effect of diverse ions in the determinations $\left(2.0 \mu \mathrm{g} \mathrm{mL} \mathrm{m}^{-1}\right)$ of periodate

\begin{tabular}{lc}
\hline Foreign ions & $\begin{array}{c}\text { Tolerance limit } \\
\left(\mu \mathrm{g} \mathrm{mL} \mathrm{mL}^{-1}\right)\end{array}$ \\
\hline $\mathrm{Na}^{+}, \mathrm{K}^{+}, \mathrm{Ba}^{2+}, \mathrm{Sr}^{2+}$, & 1000 \\
$\mathrm{~F}^{2} \mathrm{EDTA}$ & \\
$\mathrm{PO}_{4}^{3-}, \mathrm{SO}_{4}^{2-}, \mathrm{NO}_{3}^{-}, \mathrm{BO}_{3}^{3-}$ & \\
$\mathrm{Cl}^{3}, \mathrm{WO}_{4}^{2-} \mathrm{Ca}^{2+}, \mathrm{Ag}^{+}, \mathrm{Th}^{4+} \mathrm{Sb}^{3+}$, & 500 \\
$\mathrm{Mg}^{2+}, \mathrm{citrate}^{2+}$ tatrate, acetate, & 250 \\
$\mathrm{Al}^{3+}, \mathrm{In}^{3+}, \mathrm{Zn}^{2+}, \mathrm{Ni}^{2+}$, & \\
$\mathrm{Be}^{2+}, \mathrm{Hg}^{2+} \mathrm{Bi}^{3+}, \mathrm{Cr}^{3+}, \mathrm{Tl}^{+}, \mathrm{Mn}^{2+}$ & 200 \\
$\mathrm{~Pb}^{2+}, \mathrm{Co}^{2+}, \mathrm{AsO}_{4}^{3-}$, & 100 \\
$\mathrm{Cd}^{2+} \mathrm{Pd}^{2+}$ & \\
$\mathrm{La}^{3+}, \mathrm{Zr}^{4+}, \mathrm{Gd}^{3+}$, & 25 \\
$\mathrm{Y}^{3+}, \mathrm{Sn}^{2+}$ & \\
$* \mathrm{Fe}^{3+}, * \mathrm{Cu}^{2+}$, & $<1$ \\
$* \mathrm{Ce}^{4+}, * \mathrm{Se}^{4+}$ & \\
$\mathrm{Iodate}^{4+}$ & \\
\hline
\end{tabular}

* masked with masking agent.

of interfering species were established at those concentrations that do not cause more than $\pm 2 \%$ error in absorbance values of periodate at $2 \mu \mathrm{g} \mathrm{mL}^{-1}$ (Table 1). The results indicated that $\mathrm{Cu}$ (II), $\mathrm{Fe}(\mathrm{III}), \mathrm{Ce}(\mathrm{IV}), \mathrm{Se}(\mathrm{IV})$ and iodate were found to interfere. However, the tolerance level for these ions may be increased by the addition of $1 \mathrm{~mL}$ of $1 \%$ EDTA.

\section{Application}

The proposed method was applied to the quantitative determination of periodate in solution and various river water samples, the results are presented in Table 2 and 3 respectively. Statistical analysis of the results by $t$ - and $F$ tests showed no significant difference in accuracy and precision of the proposed and reference method. ${ }^{17}$ The precision of the proposed method was evaluated by replicate analysis of samples containing periodate at three different concentrations. 
Table 2. Determination of periodate in river water samples

\begin{tabular}{|c|c|c|c|c|c|c|c|c|c|}
\hline \multirow[t]{2}{*}{ Sample } & \multirow{2}{*}{$\begin{array}{l}\text { Periodate added } \\
\quad\left(\mu \mathrm{g} \mathrm{mL} L^{-1}\right)\end{array}$} & \multicolumn{3}{|c|}{ Proposed method } & \multicolumn{5}{|c|}{ Reference method } \\
\hline & & $\begin{array}{l}\text { Periodate found } \\
\quad\left(\mu \mathrm{g} \mathrm{mL} \mathrm{mL}^{-1}\right)\end{array}$ & $\begin{array}{l}\text { Relative } \\
\text { error }(\%)\end{array}$ & $\begin{array}{l}{ }^{b} \mathrm{RSD} \\
(\%)\end{array}$ & $\begin{array}{l}\text { Periodate found }{ }^{a} \\
\quad\left(\mu \mathrm{g} \mathrm{mL}^{-1}\right)\end{array}$ & $\begin{array}{l}\text { Relative } \\
\text { error }(\%)\end{array}$ & $\begin{array}{l}{ }^{\mathrm{b}} \mathrm{RSD} \\
(\%)\end{array}$ & ${ }^{c}$ t-test & ${ }^{\mathrm{d}} \mathrm{F}$-test \\
\hline $\begin{array}{l}\text { River } \\
\text { water-1 }\end{array}$ & $\begin{array}{l}1.0 \\
3.0 \\
5.0\end{array}$ & $\begin{array}{l}0.994 \pm 0.021 \\
2.998 \pm 0.014 \\
4.990 \pm 0.015\end{array}$ & $\begin{array}{l}-0.60 \\
-0.06 \\
-0.20\end{array}$ & $\begin{array}{l}2.11 \\
0.47 \\
0.31\end{array}$ & $\begin{array}{l}0.992 \pm 0.018 \\
3.010 \pm 0.022 \\
5.010 \pm 0.024\end{array}$ & $\begin{array}{l}-0.80 \\
+0.33 \\
+0.20\end{array}$ & $\begin{array}{l}1.81 \\
0.73 \\
0.48\end{array}$ & $\begin{array}{l}0.42 \\
1.58 \\
2.43\end{array}$ & $\begin{array}{l}1.36 \\
2.46 \\
2.56\end{array}$ \\
\hline $\begin{array}{l}\text { River } \\
\text { water-2 }\end{array}$ & $\begin{array}{l}1.0 \\
3.0 \\
5.0\end{array}$ & $\begin{array}{l}0.992 \pm 0.019 \\
3.010 \pm 0.018 \\
5.020 \pm 0.040\end{array}$ & $\begin{array}{l}-0.80 \\
+0.33 \\
+0.48\end{array}$ & $\begin{array}{l}1.92 \\
0.59 \\
0.79\end{array}$ & $\begin{array}{l}0.997 \pm 0.023 \\
3.020 \pm 0.024 \\
5.030 \pm 0.030\end{array}$ & $\begin{array}{l}-0.30 \\
+0.60 \\
+0.60\end{array}$ & $\begin{array}{l}2.31 \\
0.79 \\
0.59\end{array}$ & $\begin{array}{l}0.86 \\
1.13 \\
0.51\end{array}$ & $\begin{array}{l}1.47 \\
1.78 \\
1.78\end{array}$ \\
\hline $\begin{array}{l}\text { River } \\
\text { water-3 }\end{array}$ & $\begin{array}{l}1.0 \\
3.0 \\
5.0\end{array}$ & $\begin{array}{c}0.997 \pm 0.03 \\
3.010 \pm 0.05 \\
5.02 \pm 0.04\end{array}$ & $\begin{array}{l}-0.30 \\
+0.33 \\
+0.40\end{array}$ & $\begin{array}{l}3.07 \\
1.66 \\
0.79\end{array}$ & $\begin{array}{c}0.944 \pm 0.02 \\
3.031 \pm 0.07 \\
5.04 \pm 0.06\end{array}$ & $\begin{array}{l}-0.60 \\
+1.0 \\
+0.80\end{array}$ & $\begin{array}{l}2.01 \\
2.30 \\
1.19\end{array}$ & $\begin{array}{l}0.19 \\
0.52 \\
0.62\end{array}$ & $\begin{array}{l}2.25 \\
1.96 \\
2.25\end{array}$ \\
\hline $\begin{array}{l}\text { River } \\
\text { water-4 }\end{array}$ & $\begin{array}{l}1.0 \\
3.0 \\
5.0\end{array}$ & $\begin{array}{l}0.993 \pm 0.02 \\
2.998 \pm 0.02 \\
4.980 \pm 0.03\end{array}$ & $\begin{array}{l}-0.70 \\
-0.60 \\
-0.40\end{array}$ & $\begin{array}{l}1.41 \\
0.67 \\
0.60\end{array}$ & $\begin{array}{c}0.995 \pm 0.025 \\
3.020 \pm 0.03 \\
5.020 \pm 0.05\end{array}$ & $\begin{array}{l}-0.50 \\
+0.60 \\
+0.40\end{array}$ & $\begin{array}{l}2.51 \\
0.99 \\
0.99\end{array}$ & $\begin{array}{l}0.16 \\
1.39 \\
1.54\end{array}$ & $\begin{array}{l}3.18 \\
2.25 \\
2.78\end{array}$ \\
\hline $\begin{array}{l}\text { River } \\
\text { water-5 }\end{array}$ & $\begin{array}{l}1.0 \\
3.0 \\
5.0\end{array}$ & $\begin{array}{c}0.955 \pm 0.018 \\
3.02 \pm 0.04 \\
5.01 \pm 0.024\end{array}$ & $\begin{array}{l}-0.5 \\
+0.20 \\
+0.60\end{array}$ & $\begin{array}{l}1.81 \\
1.32 \\
0.48\end{array}$ & $\begin{array}{c}0.992 \pm 0.02 \\
2.98 \pm 0.06 \\
4.99 \pm 0.03\end{array}$ & $\begin{array}{c}-0.80 \\
-0.20 \\
0.67\end{array}$ & $\begin{array}{l}2.01 \\
0.60 \\
2.01\end{array}$ & $\begin{array}{l}0.25 \\
2.01 \\
0.60\end{array}$ & $\begin{array}{l}1.23 \\
2.25 \\
1.56\end{array}$ \\
\hline
\end{tabular}

${ }^{a}$ Average \pm Standard deviation; ${ }^{\mathrm{b}} \mathrm{RSD}$ - Relative standard deviation; ${ }^{\mathrm{c}}$ Tabulated t-value for four degree of freedom at $\mathrm{P}(0.95)$ is 2.78 ; ${ }^{\mathrm{d}}$ Tabulated F-value for $(4,4)$ degree of freedom at $\mathrm{P}(0.95)$ is 6.39 .

Table 3. Determination of periodate in potassium periodate solution using azure $\mathrm{B}$ as a reagent

\begin{tabular}{ccccc}
\hline $\begin{array}{c}\text { Periodate } \\
\text { present } \\
\left(\mu \mathrm{g} \mathrm{mL} \mathrm{m}^{-1}\right)\end{array}$ & $\begin{array}{c}\text { Periodate } \\
\text { found }^{\mathrm{a}} \\
\left(\mu \mathrm{g} \mathrm{mL}^{-1}\right)\end{array}$ & $\begin{array}{c}\text { Relative } \\
\text { error } \\
(\%)\end{array}$ & $\begin{array}{c}\text { 'RSD } \\
(\%)\end{array}$ & $\begin{array}{c}\text { Student } \\
t \text {-value }^{\mathrm{c}}\end{array}$ \\
\hline 0.2 & $0.199 \pm 0.03$ & -0.50 & 1.51 & 0.07 \\
0.8 & $0.799 \pm 0.04$ & -0.13 & 1.25 & 0.06 \\
2.0 & $2.01 \pm 0.01$ & +0.50 & 0.50 & 2.23 \\
3.0 & $2.98 \pm 0.05$ & -0.67 & 1.67 & 0.89 \\
4.0 & $4.02 \pm 0.02$ & +0.50 & 0.49 & 2.24 \\
5.0 & $5.03 \pm 0.04$ & +0.60 & 0.79 & 1.68 \\
5.5 & $5.49 \pm 0.01$ & -0.18 & 0.18 & 2.23 \\
\hline
\end{tabular}

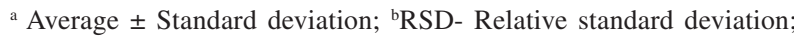
${ }^{c}$ Tabulated $t$-value for four degree of freedom at $\mathrm{P}(0.95)$ is 2.78 .

\section{Conclusions}

For the first time, azure B has been used as a chromogenic reagent for the spectrophotometric determination of periodate. The proposed method, which is simple and rapid, offers the advantages of sensitivity and wide range of determinations with out the need for extraction or heating. The method does not involve any stringent reaction conditions. The proposed method has been successfully applied to the determination of periodate in solution and various river water samples.

\section{Acknowledgements}

Authors thank the Microtron Centre of Mangalore University, Mangalore, for the technical help.

\section{References}

1. Townshend, A.; Burns, D.T.; Talanta 1992, 39, 715.

2. El- Shahawi, M. S.; Farag, A. B.; Anal. Chim. Acta 1995, 307, 139.

3. Gaikwad, A.; Silva, M.; Perez- Bendito, D.; Analyst 1994, 119,1819

4. Radhakrishnamurthi, P. S.; Panda, H. P.; React. Kinet. Catal. Lett. 1980, 14, 193.

5. Evmiridis, N. P.; Analyst 1987, $112,825$.

6. Haree, Z. A. K.; Microchem. J. 1985, 31 , 375.

7. Mohamed, A.; Tiwari, S.; J. Planar. Chromatogr. Mod. Tlc. 1991, 4, 485.

8. Honda, S.; Suzuki, K.; Kakehi, K.; Anal. Biochem. 1989, 177, 62.

9. Elmosalamy, M. A. F.; Moody, G. J.; Thomas, J. D. R.; Hassan, S. S. M.; Anal. Lett. 1987, 20, 1541.

10. Jie, N.; Yang, D.; Zhang, Q.; Yang, J.; Song, Z.; Anal. Chim. Acta 1998, 359, 87.

11. Mochnon, M. C.; Munoz Leyva, J. A.; Anal. Chim. Acta 1982, 140, 2271.

12. Verma, K. K.; Gupta, D.; Sanghi, S. K.; Arcana, J.; Analyst 1987, 112, 1519.

13. Afkhami, A.; Mosaed, F.; Michrochem. J. 2001, 68, 35.

14. Guernet, M.; Bull. Soc. Chim. Fr. 1964, 3, 478.

15. Stefania, P.; Chem. Anal. 1972, 17, 1267.

16. Mahuzier, G.; Kirkacharian, B.A.; Harfouche-Obeika, C.; Anal. Chem. 1975, 76, 79

17. Berzas Nevado, J. J.; Gonzalez, P. V.; Analyst 1989, 114, 989. 